\title{
WAJAH BARU PESANTREN DI MADURA; Studi tentang Pemikiran, Dinamika dan Kontribusi Pondok Pesantren Mambaul Ulum Pamekasan
}

\author{
Hidayatul Mutmainah', Sitti Atiyatul Mahfudoh'2 \\ 1, 2IAI Al Khairat Pamekasan
}

\begin{abstract}
ABSTRAK
Secara umum pesantren lebih mengedepankan ilmu agama Islam dibandingkan mata pelajaran umum. Hal ini dapat dilihat dari proses pembelajaran yang menggunakan kitab Islam klasik, tradisi dan beberapa kegiatannya. Penelitian ini bertujuan untuk menganalisis skema baru pesantren di Madura di mana masyarakatnya dikenal kental akan ilmu agama. Penelitian ini bersifat deskriptif kualitatif dengan objek penelitian pondok pesantren Mambaul Ulum Bata-bata Pamekasan Madura. Dari penelitian ini penulis melihat bahwa pesantren Mambaul Ulum - yang merupakan salah salah pesantren besar di Madura - kini menampilkan wajah barunya. Pesantren tersebut sekarang lebih bersifat dinamis, terbuka, dan mampu menjadi penggerak perubahan yang diinginkan. Meskipun pola perubahan bersifat sporadis, namun pesantren Mambaul Ulum Bata-bata telah mengambil kesepakatan untuk tetap mempertahankan tradisi pesantren yang telah terbangun sejak dulu dan mengikuti tren perkembangan zaman dan tekhnologi. Bentuk perubahannya menekankan aspek sistem pendidikan, kurikulum, pola pembelajaran dan lain sebagainya. Dengan menerapkan model pendidikan salaf dan khalaf secara terpadu, pesantren ini mampu mempengaruhi masyarakat di sekitarnya dalam mengembangkan pendidikan Islam.

Kata Kunci: Pemikiran Pendidikan Islam, Pesantren, Madura, Dinamika Pesantren.

\section{ABSTRACT}

In general, pesantren prioritize Islamic religious knowledge over general subjects. This can be seen from the learning process that uses classical Islamic books, traditions and some of their activities. This study aims to analyze the new scheme of pesantren in Madura where the people are known to be thick with religious knowledge. This research is descriptive qualitative with the object of research is pesantren Mambaul Ulum Bata-Bata Pamekasan Madura. From this research, the writer sees that pesantren Mambaul Ulum - which is one of the big pesantren in Madura - is now showing its new face. The pesantren is now more dynamic, open, and capable of being the driver of the desired change. Although the pattern of change is sporadic, pesantren Mambaul Ulum Bata-bata has taken an agreement to maintain the pesantren tradition that has been built for a long time and follows the trends of the times and technology. The form of change emphasizes aspects of the education system, curriculum, learning patterns and so on. By implementing an integrated model of salaf and khalaf education, this pesantren is able to influence the surrounding community in developing Islamic education.

Keywords: Islamic Education Thought, Pesantren, Madura, The Dynamics of the Pesantren
\end{abstract}

\section{A. Pendahuluan}

Di antara problem klasik yang hingga saat ini masih menghantui dunia pendidikan Islam adalah masalah konsep pendidikan Islam, di mana sampai saat ini belum menemukan format yang ideal. Banyak sekali umat Islam yang berpandangan bahwa disiplin ilmu agama terbatas pada ilmu-ilmu semisal hadits, al-Qur'an, fiqh, tarikh Islam dan sebagainya. ${ }^{1}$ Sedangkan disiplin ilmu di luar itu, seperti ekonomi,

\footnotetext{
1 S. Niyozov \& N. Memon, "Islamic Education and Islamization: Evolution of Themes, Continuities and New Directions", Journal of Muslim Minority Affairs, Vol. 5 (2011): 30.
} 
fisika, kimia, astronomi, seni, kedokteran, politik, dan budaya dan ilmu-ilmu sejenisnya dikategorikan sebagai disiplin ilmu non-agama atau sekuler. ${ }^{2}$

Itu sebabnya, tujuan pendidikan Islam harus mencakup aspek kognitif, afektif, psikomotorik, spiritual dan sosial kemasyarakatan. ${ }^{3}$ Dapat dipahami bahwa tujuan pendidikan Islam sangat luas. Seperti yang sebagian pendapat mengatakan bahwa untuk menjadikan insan kamil. Tujuan ini bersifat universal yang mencakup semua aspek dalam diri manusia. Pendidikan Islam tidak hanya menginginkan manusia baik kepada tuhannya, akan tetapi juga dituntut baik sesama manusia, dan alam. ${ }^{4}$

Dari tujuan pendidikan Islam tersebut, Mujammil Qomar “menunjuk” pesantren sebagai lembaga pendidikan ideal. ${ }^{5}$ Lembaga pendidikan Islam tertua di Indonesia tersebut memiliki daya tarik untuk diamati, diteliti, dan didialogkan, terlepas dari adanya kelemahan dan kelebihannya. ${ }^{6}$ Sebagai lembaga pendidikan Islam, di samping ototritas kiai untuk membuat model-model sesuai dengan keinginannya, pesantren hingga kini telah berkembang dengan berbagai variasinya sehingga sulit digeneralisasikan. Selanjutnya, karena agama (Islam) sumbernya dari Tuhan, dengan sendirinya, ilmu juga sumbernya dari Tuhan, yang berarti seluruh aktifitas terkait dengan proses transmisinya juga tidak boleh dilepaskan dari nilai-nilai dan normanorma Ketuhanan. ${ }^{7}$ Oleh karena itu, jelas bahwa aktifitas belajar-mengajar dalam perspektif Islam sebenarnya bermakna dan berorientasi "sarwa ibadah" dan spiritual religius.

Bahwasanya semua unsur yang berkerja di dalamnya tidak ada yang terlepas dari pengawasan nur ilahiah, termasuk keberadaan ilmu-ilmu umum yang diadopsi dari sistem pendidikan Barat. Orientasi filosofis pesantren yang bercorak "teosentris". 8 Meskipun belum terumuskan secara tuntas, sejauh ini boleh dikatakan telah berhasil dalam memberikan landasan dasar yang kuat bagi lembaga ini dalam upaya memasukkan unsur-unsur modernitas ke dalam aktifitas pendidikannya. ${ }^{9}$ Pesantren

${ }^{2}$ Mohamed Mohamed Tolba Said, et. al., “INNOVATION IN ISLAMIC EDUCATION”. Hayula: Indonesian Journal of Multidisciplinary Islamic Studies, Vol. 2, No. 2 (July 2018): 117-128.

3 Toto Suharto, Filsafat Pendidikan Islam (Yogyakarta: Ar-Ruzz Media, 2014), 86.

${ }^{4}$ Lihat, Alhaji A.D. Ajijola, Re-Structuring of Islamic Education (Delhi: Adam Publishers \& Distributors, 1999).

${ }^{5}$ Mujamil Qomar, menggagas Pendidikan Islam (Bandung: Remaja Rosdakarya, 2014), 27.

${ }^{6}$ Ibid., 20.

7 KH. Hasyim Asy’ari, Adâb al-‘Âlim wa al-Muta'alim”. Suwendi, Sejarah dan Pemikiran Pendidikan Islam (Jakarta: RajaGrafindo Persada, 2004), 9-11.

8 Zaini Tamin AR, "Dinamika Perkembangan Kurikulum Pendidikan Pesantren; Satu Analisis Filosofis". ELBANAT: Jurnal Pemikiran dan Pendidikan Islam, Vol. 8 , No. 1 (2018): 1-21. https: //doi.org/10.54180/elbanat.2018.8.1.1-21

9 Evi Fatimatur Rusydiyah, "Konstruksi sosial pendidikan pesantren: analisis pemikiran Azyumardi Azra", Jurnal Pendidikan Agama Islam (Journal of Islamic Education Studies) Vol. 5, No. 1 (2017). https://doi.org/10.15642/jpai.2017.5.1.21-43. 
Mambaul Ulum Bata-bata Pamekasan menjadi lembaga yang searah dengan dinamika tersebut. Pesantren ini menjadi bagian penggerak perubahan dan menampilkan "wajah baru"nya di tengah masyarakat Madura khas dengan tradisi kepesantrenan. Maka, penulis tidak ragu melakukan penelitian di pondok pesantren tersebut sebagai upaya menganalisis sejarah, pemikiran dan kontribusinya bagi masyarakat dan bangsa.

\section{B. Potret Pondok Pesantren Mambaul Ulum Bata-bata; Dulu dan Kini}

Pondok pesantren Mambaul Ulum Bata-Bata Pamekasan Madura merupakan pondok pesantren terbesar dengan kapasitas jumlah santri melebihi 5.000 orang. Setiap pesantren memiliki visi yang beragam, namun secara umum pesantren lebih mengedepankan ilmu agama Islam dibandingkan mata pelajaran umum. Semua itu dapat dilihat dalam proses pembelajaran yang berlangsung di pondok pesantren Mambaul Ulum Bata-Bata dengan menggunakan kitab Islam klasik, seperti ilmu nahwu, shorof, fiqih, usul fiqh, hadits, tafsir, tauhid, tasawuf dan etika. Di samping itu, santri juga diajarkan pengetahuan ilmu sejarah atau tarikh, balaghah serta cabang ilmu lainnya. Biasanya kita-kitab klasik itu menggunakan kitab yang tidak dilengkapi makna dan harkat sebagai latihan untuk pengetahuan nahwu-shorof dan balaghah.

Data tersebut dapat diperjelas dari hasil wawancara dengan salah satu pengurus pondok pesantren yakni ustad Idris menuturkan tentang pembelajaran umum dan agama islam, berikut paparannya:

"di pesantren Mambaul Ulum Bata-bata mulai dari pengasuh terdahulu hingga pengasuh saat ini, bata-bata terkenal dengan pondok salaf nya, yang mana pembelajaran lebih difokuskan pada ilmu agama saja. Seperti kitab, fiqih, usul fiqh, hadist, tauhid, dan etika. Namun santri juga dibekali alat untuk belajar kitab salaf tersebut seperti jurmiah, nahwu dan shorrf, dan karena kitab yang dipakai santri bata-bata tidak berharokat dan tidak bermakna"10.

Hal demikian juga diperkuat oleh hasi wawancara penulis dengan salah satu ustadzah yakni ustdzah in, beliau juga sependapat dengan penerapan ilmu pembelajaran di bata-bata, berikut paparannya:

"mulai dari saya mondok hingga menjadi ustdzah di pesantren ini, bata-bata masih seperti dulu, masih dengan bau-bau salafnya. Banyak kitab kuning dan kitab gundul ${ }^{11}$ yang dipelajari oleh santri. Namun melihat perkembangan zaman meskipun pondok salafi, pesantren bata-bata juga mengikuti perkembangan zaman dengan menggandeng ilmu umum. Namun yang tetap diperioritaskan adalah ilmu agama islamnya." 12

\footnotetext{
10 Idris, Ustda santri putra, Wawancara langsung (5 november 2021).

11 Kitab yang tidak berharkat dan tidak bermakna

12 lin, Ustdazah santri putri, Wawancara langsung (5 november 2021).
} 
Peneliti mengamati bahwa setiap pagi di Bata-bata diadakan program Pendidikan umum dan agama, seperti sekolah-sekolah umum. Yakni Mts, Mi, Smk dan MA dan ketika malam diadakan pembelajaran khsus agama yakni kajian kitab kuning.

Seluruh pesantren yang ada di Nusantara hampir sama mengajarkan pengetahuan seperti yang diterapkan di pondok pesantren Mambaul Ulum Bata-Bata di atas dengan metode sorogan dan bandongan. ${ }^{13}$ Tujuan utamanya adalah mendidik calon ulama. Pesantren Mambaul Ulum Bata-bata merupakan salah satu pesantren yang selalu menjadi rujukan penelitian kajian kepesantrenan. Disini akan di paparkan bagaimana pesantren Mambaul Ulum Bata-Bata mendidik santrinya. Sehingga akan lebih mudah memahami arah pendidikan pesantren. Karena masih ada pengamat yang menyudutkan pesantren sebagai lembaga pendidikan yang jumud dan kaku. Tetapi stigma itu tidak membuat pesantren bubar, namun tetap bertahan dengan dinamika sosial karena terus mendapatkan kepercayaan dari masyarakat. ${ }^{14}$

Di pesantren ini juga memberi penguatan bahwa di pondok ini mempunyai tenaga pendidik yang notabanenya dari luar pesantren untuk mengajar di bidang umum, sehingga tenaga pendidik yang dari dalam dikhususkan mengajar ilmu agama, dan ini juga diperkuat dengan adanya surat lamaran guru. ${ }^{15}$ Perkembangan pendidikan yang disediakan pesantren ini menunjukkan bahwa arah pesantren bukan hanya sekedar untuk mendidik calon ulama. Sebab santri juga disediakan penngetahuan umum sebagai respon atas perubahan sosial yang terjadi hingga plosok desa. Pesantren juga mempersiapkan tantangan zaman yang semakin maju. ${ }^{16}$

Pesantren Mambaul Ulum Bata-Bata menyelenggarakan beberapa 9 model pendidikan, di antaranya kelas Bandongan, kelas Sorogan, Madrasah Ibtidaiyah, Sekolah Persiapan Tsanawiyah, sekolah persiapan Aliyah, Madrasah Tsanawiyah, Madrasah Aliyah, SMK, dan Institut Agama Islam Al-Khairat. Maka dalam perkembangannya, dari 9 jenis pendidikan yang diterapkan tujuan pendidikan Mambaul Ulum Bata-Bata lebih luas, yaitu mendidik santri untuk dapat mengembangkan dirinya menjadi 'ulama intelektual (ulama yang menguasai pengetahuan umum) dan 'intelektual ulama' (sarjana dalam bidang pengetahuan umum yang juga mengusai pengetahuan Islam).

\footnotetext{
13 Zaini Tamin AR, Kusaeri Kusaeri, Hanik Yuni Alfiyah, and Nia Indah Purnamasari. “MENAKAR BUDAYA LITERASI DI PESANTREN; Siginifikansi Dan Relevansi Metode Programme for International Student Assessment". FIKROTUNA, Vol. 13, No. 01 (2021). https://doi.org/10.32806/jf.v13i01.4356.

14 Observasi, 1-2 November 2021

15 Dokumen tentang tenaga pendidik yang dari luar pesantren

16 Ibid., 186.
}

El Banat Vol. 11 No. 2 (2021)

166 
Data tersebut diperjelas oleh hasil wawancara penulis dengan salah satu pengurus yakni ustad Idris, beliau mengemukakan:

"pondok pesantren mabaul ulum bata-bata ini adalah pondok yang kental dengan salafiyahnya namun kendati demikian pondok ini tidak menampik dengan perkembangan zaman dan tekhnologi, pondok ini menyelaraskan pembelajaran atau pendidikannya sesuai tuntutan zaman, seperti yang kita ketahui Bersama bahwa sudah terdapat 9 model Pendidikan yang dikembangkan di bata-bata ini, yakni ada kelas sorogan, kelas bandongan, madrasah Ibtidaiyah, Madasah Tsanawiyah, Madrasah Aliyah, SMK, dan perguruan tinggi. Bahkan santri yang menjadi mahasiswa ini diberikan kelonggaran untuk memegang alat komunikasi (hp) yang diepruntukkan supaya mahasiswa Ketika ada tugas online tidak repot untuk keluar pondok"17

Senada dengan hal tersebut, ustadzah iin juga menegaskan bahwa:

“pondok bata-bata ini tidak ingin santrinya ketika keluar dari pesantren ketinggalan zaman, meskipun santri ini seperti dikurung dan tidak memegang hanphone untuk mengakses perkembangan dan informasi di luar sana. Di pesantren ada banyak informasi yang bisa diakses melalui koran, dan radio. Kemudian di pondok ini banyak santri yang sudah dikirim ke perguruan tinggi di luar negeri seperti mesir, china dll. Dan juga banyak santri yang sudah menjuarai lomba-lomba di bidang umum, seperti sains, matematika dll."18

Dari hasil pengamatan peneliti bahwa setiap pagi ada kajian kitab kuning berupa kitab fiqih, al-qur'an, dengan model sorogan dan bandongan. Setiap malam peneliti mengamati kajan kitab kuning dengan ilmu alatnya yang menggunakan model sorogan. Namun kemudian munculnya Perguruan Tinggi (PT) di sejumlah pesantren -tak terkecuali di Mambaul Ulum Bata-Bata sebagai bukti bahwa pendidikan di pesantren sangat komplek, mulai menjaga tradisi dari ulama terdahulu hingga mengadopsi model pendidikan modern. Ini artinya pesantren sangat terbuka terhadap perkembangan zaman tanpa meninggalkan sesuatu yang sudah menjadi karakter dari pesantren itu sendiri. Sehingga pesantren tetap menjadi institusi yang selalu ‘kokoh' hingga sekarang dengan mengadakan pelatihan umum baik di intra ataupun ekstra khusus untuk guruguru umum. Komunikasi secara langsung ditunjukkan bahwa nampak di ruang kelas terdapat guru yang mengajar di bidang umum, dan ustdzah dibidang agama. ${ }^{19}$

Di lembaga ini juga memberikan penguatan bahwa di pesantren ini mempunyai sertifikat tentang kejuaraan lomba tingkat nasional khusunya dan ada rekom pengiriman santri untuk melanjutkan studinya ke luar negri, terdapat pula gedung sekolah yang beralntai 3 untuk sarana penerapan 8 model Pendidikan dan untuk 1

17 Idris, Ustda santri putra, Wawancara langsung (5 november 2021).

18 lin, Ustdazah santri putri, Wawancara langsung (5 november 2021).

19 Observasi, 1-2 November 2021 
model Pendidikan yang sekarang sudah menajdi institute Agama Islam Al-Khairat Pamekasan dengan 8 jurusan yang sudah terakreditasi. ${ }^{20}$

Ahmad Baso menggambarkan betapa luasnya ilmu dan pengetahuan di pesantren. Dari pesantren, kalangan santri mendapatkan ilmu pengetahuan agama dari kutub mu'tabarah untuk menyempurnakan ibadah dan bekal untuk kehidupan akhirat. Tetapi disamping itu, dari pesantren juga telah melahirkan teks-teks bahasa Bugis dari bahasa Makasar dibuat pada 1635 dan pada 1652. Teks tersebut mengajarkan ilmu-ilmu militer dan teknologi persenjataan yang dipelajari dari Spanyol dan Portugis dari abad 17. Teks-teks itu lahir dari pergumulan santri dari pesantren pertama yang didirikan oleh Syekh Alwi Assegaf dari Arab di Bontoala yang diintegrasikan Kota Makasar. Bahkan sebagian dari teks-teks itu ada di London, Inggris. Sehingga Bontoala disebut sebagai pusat penyalinan naskah dan teks-teks pesantren (scriptoria). ${ }^{21}$ Semua itu menandakan bahwa pesantren sejak dulu telah mengajarkan tentang ilmu kehidupan dunia sebagai pelengkap ilmu agama. ${ }^{22}$

Dengan demikian, sejarah ilmu pengetahuan umum di pesantren tidak hanya terjadi pada abad sekarang. Tetapi sejak dulu sudah ada meskipun metode dan model yang dikembangkan tidak seperti sekarang yang bermodel sekolah atau madarasah dengan kurikulum yang dibuat sendiri maupun dari pemerintah. Maka sesat pikir jika mengasumsikan terjadi dikotomi ilmu agama dan umum di pesantren. Pesantren memandang pengetahuan umum dan agama adalah keniscayaan. Pengetahuan umum diperlukan untuk memberikan bekal kepada santri untuk menyelesaikan masalah keduniaan. Sedangkan ilmu agama dimaksudkan sebagai jalan untuk menempuh kehidupan yang hakiki, akhirat. Keduanya terintegritas dalam pengembangan pendidikan pesantren sehingga out put yang dihasilkan lebih sempurna-dapat pengetahuan umum dan agama.

Ahmad Baso berargumen, pesantren tidak hanya berbicara kurikulum, tentang mata pelajaran, tentang guru atau tentang rekrutmen murid. Tetapi lebih jauh dari itu, pesantren juga berbicara bagaimana tujuan dan desain bangsa ini. Hal itu dapat dilihat pada era penjajahan hingga sekarang, bahwa keterlibatan pesantren terhadap apa yang

\footnotetext{
${ }^{20}$ Dokumen tentang sertifikat juara lomba nasional, surat rekom santri menempuh Pendidikan di luar negeri

21 Ahmad Baso, Pesantren Studies a2 (Jakarta: Pustaka Afid, 2013), 275-276.

22 A. Mahmud \& Z.T. AR, "Transformasi Pesantren (Studi terhadap Dialektika Kurikulum dan Kelembagaan Pondok Pesantren Rifaiyah Pati)”, EL-BANAT: Jurnal Pemikiran dan Pendidikan Islam Vol. 9 No. 2 (2019). https://doi.org/10.54180/elbanat.2019.9.2.156-176.
} 
akan diambil atau diperbuat untuk nasib bangsa. ${ }^{23}$ Sehingga keberadaan pesantren oleh Boedi Oetomo disebut sebagai "sumber pengetahuan" dan "mata air" bagi bangsa. ${ }^{24}$

\section{Tipologi Pemikiran Pendidikan Islam di Pondok Pesantren Mambaul Ulum Bata-bata}

1. Perenial-Esensialis Salafi

Tujuan pendidikan Islam diorientasikan pada upaya membantu peserta didik dalam menguak menemukan kebenaran masa lalu pada masa salaf al-Shalih; dan menjelaskan dan menyebarkan warisan sejarah dan budaya salaf melalui sejumlah inti pengetahuan yang terakumulasi yang telah belaku sepanjang masa. ${ }^{25}$ Model ini adalah pemikiran pendidikan Islam yang selalu mengacu pada wawasan pemikiran pendidikan Islam yang berkembang pada era salafi-masa Rosulullah dan para sahabat yang dinilai sebagai masyarakat ideal. Pemikiran ini sebagai upaya melestarikan dan mempertahankan nilai-nilai Insaniah dan Ilahiah, tradisi dan budaya yang berlangsung pada masyarakat salaf. ${ }^{26}$ Model ini berupaya memahami ajaran-ajaran dan nilai-nilai dasar yang terkadung dalam al-Qur'an dan al-Sunnah. Kedua sumber itu dipahami secara tekstual dengan melepaskan diri dari perkembangan zaman.

Konstruksi tipologi tekstual salafi dilihat dari wataknya yang bersifat regresif dan konservatif, maka lebih dekat dengan perenialism dan essensialism. Hanya saja perenialism menghendaki agar kembali kepada jiwa yang menguasai abad pertengahan, sedangkan model tekstual salafi menghendaki agar kembali ke masyarakat salaf (era kenabian dan sahabat). Namun pada intinya keduanya lebih berwatak regresif. Adapun essentialism menghendaki pendidikan yang bersendikan atas nilai-nilai yang tinggi, yang hakiki kedudukannya dalam kebudayaan, dan nilainilai ini hendaklah yang sampai kepada manusia melalui civilisasi dan yang telah teruji oleh waktu. ${ }^{27}$

\footnotetext{
${ }^{23}$ Ahmad Baso, Pesantren Studies 2a., 16.

${ }^{24}$ Ahmad Baso, Pesantren Studies 4a (Jakarta: Pustaka Afid, 2013), 5.

${ }^{25}$ Muhaimin, Pengembangan Kurikulum Pendidikan Agama Islam di Sekolah , Madrasah, dan perguruan Tingggi (Jakarta: Rajagrafindo, 2010), 126.

${ }^{26}$ Andik Wahyun Muqayyidi, Menuju Pemetaan Tipologi Pemikiran Pendidikan Islam : Tipologi Prenial-Esensialis Kontekstual-Falsifikatif Tentang Pendidikan Islam tadzkiriah (t.tp, 2016), 103.

27 Model pemikiran tekstualis salafi juga beranggapan bahwa nilai-nilai kehidupan pada masyarakat salaf perlu dijunjung tinggi dan dilestarikan keberadaannya hingga sekarang, baik nilai-nilai insaniyah maupun nilai-nilai Illahiyah, karena masyarakat salaf dipandang sebagai masyarakat yang ideal. Karena itu keduanya juga berwatak konservatif, dalam arti sama-sama hendak mempertahankan nilai, kebiasaan dan tradisi masyarakat terdahulu. Dalam bangunan pemikiran filsafat pendidikan Islam, model ini dapat dikategorikan sebagai tipologi perennial tekstual salafi dan sekaligus essensial tekstual salafi. Parameter dari perennial -tekstual salafi adalah watak regresifnya yang ingin kembali ke masa salaf sebagai masyarakat ideal yang dipahaminya secara tekstual. Sedangkan parameter essensial-tekstual salafi adalah watak konservatifnya untuk
} 
Dengan demikian, tipologi pemikiran pendidikan Islam yang tidak terbuka ini akan mengalami kendala dalam perkembangan dunia pesantren sebagai lembaga pendidikan Islam maupun dalam pendidikan Islam lainnya. Model ini jika diterapkan di pesantren secara pelan akan ditinggal oleh masyarakat. Masyarakat menginginkan pendidikan Islam juga mampu bersaing dengan pendidikan modern. Apalagi pesantren akhir-akhir ini memiliki kekuatan yang luar biasa terutama dalam mengembangkan pendidikan Islam. Belum ditemukan pengembangan pendidikan Islam yang sejajar keseriusannya dengan pesantren yang konsisten mendalami ilmuilmu agama dan IPTEK dengan berlandaskan nilai-nilai Ilahiah.

Dari hasil data yang penulis temukan di Pesantren Mambaul Ulum Bata-Bata sejak dahulu menerapkan model pendidikan sistem salaf, yang mana model pendidikan di pondok ini lebih di fokuskan pada nilai insaniyah dan ilahiyah saja. Model pesantren masih memegang teguh nilai dasar pesantren yakni semua hal yang dilakukan dilandasi sebagai bagian dari ibadah kepada Allah SWT., nilai itu menjadi dasar penyelenggaraan pendidikan yang dilakukan oleh pengasuh dan ustadz. Penyelenggaraan pendidikan yang masih menggunakan kitab kuning merupakan realisasi dari sistem nilai yang masih di anut oleh pesantren Mambaul Ulum BataBata yakni ahlussunnah waljama'ah.

Sumber belajar utama pesantren salafi terutama di pesantren Mambaul Ulum Bata-Bata yang digunakan di pesantren-pesantren Indonesia sebenarnya sangat beragam diantaranya adalah matan al-Jurumiyyah, Imrithy (Nahwu, Fath al-Qorib, Fath al-Mu'in (Fiqh), Durus al-Aqoid al-diniyah (Tauhid), Ayat al-Ahkam min alQur'an (Tafsir), Bidayah al-Hidayah dan lain sebagainya. ${ }^{28}$

Hal ini sesuai dengan wawancara kai dengan pengasuh pondok pesantren mabaul ulum bata-bata yakni ning Ummuh, berikut paparannya:

“meskipun sekarang sudah zamannya tekhnologi yang canggih, akan tetapi
pesantren bata-bata tetap bisa berkolaborasi terkait keilmuan dan Pendidikan
santri, pesantren disni sangat kental dengan ilmu dan ajaran salafi, namun kendati
demikian peantren kami juga bisa mengakses informasi melalui tekhnologi bahkan
selain kurikulum yang berbasih pesantren atau keagamaan kurikulum di sekolah ini
sudah sesuai dengan kurikulum sekarang yakni K-13. Kami tetap konsisten dalam
mendalami ilmu-ilmu agama dan IPTEK tapi tidak lepas dari nilai-nilai ilahiyah "29

mempertahankan dan melestarikana nilai-nilai Illahiyah dan insaniyah yang dipraktikkan pada masa salaf yang juga dipahami secara tekstual tanpa adanya verifikasi dan kontekstualisasi. Untuk menyederhanakan istilah pada model filsafat pendidikan Islam pada tipologi ini kita pakai istilah perennial-essensial salafi, Muhaimin, Wacana Pengembangan Pendidikan Islam (Yogyakarta: Pustaka pelajar, 2003), 32-35.

28 Observasi 3 November 2021

${ }^{29}$ Ning Ummuh, Pengasuh Bata-Bata (wawancara langsung 7 November 2021)

El Banat Vol. 11 No. 2 (2021)

$170 \mid$ 
Hal demikian juga sependapat dengan hasil wawancara $\mathrm{kam}^{30} \mathrm{i}$ Bersama kepala sekolah MA, berikut paparannya

"basis pendidikan di pesantren bata-bata ini sudah canggih, tingkat Pendidikannya
disini sudah banyak, dan sudah bertekhnologi. Kurikulum yang kami pakai sudah
sesuai dengan K-13 berkaitan dengan mata pelajaran umum. Pendidikan salafiyah
juga masih kai terapkan disini sebagai salafi para leluhur seperti penggunaan kitab
matan al-Jurumiyyah, Imrithy (Nahwu, Fath al-Qorib, Fath al-Mu'in (Fiqh), Durus
al-Aqoid al-diniyah (Tauhid), Ayat al-Ahkam min al-Qur'an (Tafsir), Bidayah al-
Hidayah dan lain sebagainya."

Dengan hasil analisis dokumen, menunjukkan bahwa adanya RPP oleh masing-masing guru, adanya buku mata pelajaran dan ruang LAB serta kitab-kitab kuning yang berada di ruang musholla, dan beberapa tenga pendidik umum dari lar pesantren. ${ }^{31}$

2. Perenial-Esensialis Mazhabi

Melalui khazanah pemikiran klasik tanpa memepertimbangkan situasi sosiohistoris masyarakat setempat dimana ia turut hidup didalamnya. Hasil pemikiran/ijtihad ulama terdahulu dianggap sudah final atau absolut tanpa memepertimbangkan dimensi historisitasnya. Kitab kuning menjadi rujukan pokok dan sulit keluar dari mazhab atau pemikiran keislaman yg terbentuk abad lalu. Jadi yang menonjol watak tradisionalnya dan mazhab. Watak tradisional diwujudkan dalam bentuk sikap dan cara berfikir serta bertindak yng selalu berpegang teguh kepada nilai, norma, adat- istiadat, kebiasaan serta pola pikir yang yang ada secara turun-temurun, tidak mudah mengalami perubahan dan perkembangan. Sedangkan mazhabinya terwujud dari dalam bentuk kecenderungan untuk mengikuti aliran, pemahaman atau doktrin, serta pola-pola pemikiran sebelumnya yang sudah dianggap relatif mapan. ${ }^{32}$

Model yang kedua ini merupakan tipologi Islam yang tradisional dan kecenderungan untuk mengikuti aliran, pemahaman atau doktrin. Model yang kedua ini sebenarnya hampir mirip dengan model yang pertama,yakni sama-sama mengembalikan pemahaman dan semua persoalan keislaman pada masa lalu. Jika tipologi perenial-esensial salafi mengacu pada masa kenabian Muhammad SAW. dan para sahabat, maka tipologi perenial-esensialis mazhabi mengacu pada mazhab yang telah berhasil melakukan ijtihad setelah Nabi dan sahabat. Golongan semacam ini selalu berkeyakinan bahwa hasil ijtihad pemikir Islam setelah Nabi dan sahabat

\footnotetext{
${ }^{30}$ Kepala sekolah MA (wawancara langsung 7 November 2021)

31 Dokumen tentang RPP dan Ruang LAb

32 Mustafa, Mazhab Filsafat Pendidikan Dan Implikasinya Terhadap Pendidikan Islam, (Jurnal Pendidikan Islam lqra', 2018)., 21.
} 
sesuatu yang absolut tanpa melihat sejarah yang mengitari kehidupan di masa itu. Parameter dari pemikiran ini juga bersumber dari al-Quran dan al-Sunnah, regresif ke masa lampau atau pemikiran ulama klasik dan mempertahankan tradisi dan mempertahankan pemikiran pendahulunya secara turun temurun. ${ }^{33}$

Tipologi tersebut berusaha membangun konsep pendidikan Islam melalui kajian terhadap khazanah pemikiran pendidikan Islam karya para ulama periodeperiode terdahulu, baik dalam struktur tujuan, kurikulum atau program pendidikan maupun lingkungan belajar. Bahkan juga merujuk atau mengadopsi produk-produk pemikiran dari para cendekiawan non Muslim terdahulu tanpa dibarengi dengan daya kritis yang memadai. ${ }^{34}$

Perenial-Esensialis Mazhabi, Konstruksi tipologi tradisional mazhabi dilihat dari wataknya lebih menonjolkan sifatnya yang tradisional dan mazhabi. Watak tradisionalnya diwujudkan dalam bentuk sikap dan cara berfikir serta bertindak yang selalu berpegang teguh pada nilai, norma dan adat kebiasaan serta pola-pola pikir yang ada secara turun menurun dan tidak mudah terpengaruh oleh situasi sosio historis masyarakat yang sudah mengalami perubahan dan perkembangan sebagai akibat dari kemajuan ilmu pengetahuan dan teknologi. Sedangkan watak mazhabinya diwujudkan dalam bentuk kecenderungannya untuk mengikuti aliran, pemahaman atau doktrin, serta pola-pola pemikiran sebelumnya yang dianggap sudah relatif mapan. ${ }^{35}$

Dari hasil pengamatan peneliti bahwa Tipologi pemikiran ini sangat kuat. Meskipun pesantren mabaul ulum bata-bata sebagai pusat pendidikan Islam mulai berkembang dari salaf, semi salaf hingga modern, mayoritas kalangan pesantren khususnya bata-bata mengikuti sejumlah mahzab terutama empat mahzab, diantaranya Imam Hambali, Maliki, hanafi dan imam Syafi'ie. Hasil ijtihad dari empat imam ini, yang paling banyak pengikutnya adalah imam Syafi'ie. Dengan kata lain, masalah mahzab masih melekat dalam kehidupan umat muslim terutama dunia

33 Muhaimin, Wacana Pengembangan, 32-35.

34 Ali Muttaqin, Implikasi Aliran Filsafat Pendidikan Dalam Pengembangan Kurikulum Pendidikan Islam, (Dinamika, 2016), 67-92.

35 Dalam konteks pemikiran filsafat pendidikan Islam, tipologi ini berusaha membangun konsep pendidikan Islam melalui kajian terhadap khazanah pemikiran pendidikan Islam karya para ulama' pada periode terdahulu, baik dalam bangunan tujuan pendidikannya, kurikulum atau program pendidikan, hubungan pendidik dan peserta didik, metode pendidikan, maupun lingkungan pendidikan (konteks belajar) yang dirumuskannya. Bahkan ia juga merujuk atau mengadopsi produk-produk pemikiran pendidikan dari para cendikiawan non muslim terdahulu tanpa dibarengi dengan daya kritis yang memadai. Dengan demikian tipologi filsafat pendidikan Islam ini lebih dekat dengan perenialism dan essensialism, terutama dari wataknya yang regresif dan konservatif. Maka berdasarkan tipologi tersebut tersusunlah tipologi filsafat pendidikan yang disebut dengan perennial-esensial mazhabi, Muhaimin, Wacana Pengembangan, 32-35. 
pesantren, mulai dari pesantren salaf, semi salaf hingga modern. Setiap waktu siang semua santri mengaji 3 kitab kuning yakni bidayatul hidayah, sullam taufik dan safinatunnajah yang mana dari ketiga kitab ini terdapat pednaat empat madzhab yang berkaitan dengan kegitaan sehari-hari khussunya. ${ }^{36}$

Hal demikian sesuai dengan hasil wawancara kami dengan salah satu pengurus pondok pesantren bata-bata yakni, nyai Suadah, berikut paparannya:

"di pesantren mambaul Ulum bata-bata ini mulai dari pesantren salaf, semi salaf hingga modern masih mengikuti empat madzhab, yakni Imam Hambali, Maliki, hanafi dan imam Syafi'ie, namun yang banyak diikuti oleh para santri dan seluruh pegurus hinggal keluar dari pesantren adalah madzhab Syafi'ie. Di waktu siang santri diwajibkan mengaji tiga kitab yang didalamnya terdapat pendapat empat adzhab tersebut. Hal demikian sangat penting bagi santri sebagai pertimbangan hukum refrensi dalam menjalani kehidupan sehari-hari" ${ }^{37}$

Hal demikian senada dengan pendapat salah satu Ustad yakni ustad Baihaki, berkut paparannya:

"mulai dari para terdahulu pesantren bata-bata ini sudah berimam kepada empat madhzhab yakni Imam Hambali, Maliki, hanafi dan imam Syafi'ie, namun yang lebih banyak diikuti adalah imam Sayfi'ie. Meskipun era sekrang sudah sangat modern namun kami sebagai santri bata-bata dan alumni pada khususnya tidak meninggalkan imam yang empat ini sebagai pedoman hidup "38

Di pondok ini juga memberi penguatan bahwa setiap kajian kitab siang ada 3 kitab yang kami pelajari yakni kitab Sulam taufik, safinantunnajah dan bidayatul hidayah. Ketiga kitab ini adalah bukti bahwa kami berimam kepada emat madzhab khususya imam Syafi'ie yang mana pendapat imam ini bisa disesuaikan dengan tuntutan zaman. ${ }^{39}$

3. Modernis

Pada umunya, yang dimaksud dengan modern adalah sesuatu yang baru, berbeda dengan sesuatu yang sudah mapan bahkan bertentangan dengan tradisi, adat istiadat bahkan dengan nilai agama. Karena gerakan pemikiran modern akan meninggalkan yang telah atau sedang berlangsung menuju sesuatu yang baru yang dianggap lebih baik. Tetapi ada pihak yang menganggap modern adalah hal yang tidak baik karena dinilai bertentangan dengan moral yang sudah diyakini dan terbukti sejak lama. ${ }^{40}$

\footnotetext{
36 Observasi 3 November 2021

${ }^{37}$ Nyai Su'adah, Pengurus Bata-Bata (wawancara langsung 7 November 2021)

38 Baihaki, Ustad Bata-Bata putra (wawancara langsung 7 November 2021)

39 Dokumen tentang adanya kitab kuning/klasik di bata-bata

${ }^{40}$ Suparlan Suhartono, Sejarah Pemikiran Filsafat Modern (Yogyakarta: Ar- Ruzz, 2005) ,25.
} 
Model ini berupaya memahami ajaran-ajaran dan nilai-nilai mendasar yang terkandung dalam al-Qur'an dan al-sunnah al-sahih dengan mengikutsertakan dan mempertimbangkan khazanah intelektual muslim klasik serta mencermati kesulitankesulitan dan kemudahan-kemudahan yang ditawarkan oleh dunia tekhnologi modern. Jargon yang sering dikumandangkan adalah "al-muhafazah 'ala al-Qodim al-salih wa al-Akhzu bi al-jadid al-aslah, " yakni memelihara hal yang baik yang telah ada sambil mengembangkan nilai-nilai baru yang lebih baik. ${ }^{41}$ Tipologi filsafat pendidikan Islam model ini lebih menonjolkan wawasan pendidikan Islam yang bebas, modifikatif, progresif dan dinamis dalam menghadapi dan merespon tuntutan dan kebutuhan dari lingkungannya, sehingga pendidikan Islam berfungsi sebagai upaya melakukan rekonstruksi pengalaman yang terus menerus agar dapat berbuat sesuatu yang intelligent dan mampu mengadakan penyesuaian dan penyesuaian kembali sesuai dengan tuntutan dan kebutuhan dari lingkungan pada masa sekarang. ${ }^{42}$

Berdasarkan hasil pengamatan penulis, model pendidikan Islam modernis ini masih mengalami kendala dalam dunia pendidikan Islam terutama di pesantren mambaul ulum Bata-Bata. Sebab diantara tujuan pesantren dalam rangka menjaga tradisi khazanah keilmuan para ulama klasik. Sejak berdiri hingga sekarang, pesantren merupakan lembaga dakwah dan pendidikan Islam yang selalu menghormati para ulama terdahulu, mengkuti risalahnya, bukan dalam pengertian taqlid buta. Karena pesantren merupakan lembaga pendidikan Islam yang inklusif dalam menyikapi perubahan yang terjadi. Tetapi semangat perubahan dari tipologi ini menjadi inspirasi bagi pesantren untuk terus berubah. Terbukti, banyak pesantren yang mengatasnamakan diri sebagai pondok modern meskipun kurikulum didalamnya tidak sepenuhnya meninggalkan keilmuan yang bersumber dari ulama klasik. Kurikulum yang diterapkan, sama dengan lembaga pendidikan formal lainnya di PP. Mambaul Ulum Bata, yaitu perpaduan antara kurikulum pemerintah dan kurikulum pesantren, Madrasah Aliyah Mambaul Ulum Bata-Bata menginginkan peserta didik mampu meraih prestasi disegala bidang baik dalam bidang IPTEK maupun IMTAK, juga menginginkan peserta didik menjadi warga negara beriman

\footnotetext{
41 Muhaimin, Pengembangan Kurikulum Pendidikan Agama Islam di Sekolah, Madrasah dan Perguruan Tinggi (Jakarta: RajaGrafindo Persada, 2007), 98.

42 Sayyidah Saekhotin, Dialektika Fundasional Perkembangan Pesantren (Perspektif Pendidikan Islam, (AlQodiri: Jurnal Pendidikan, Sosial Dan Keagamaan, 2013), 20-35.
} 
yang kuat dan berakhlakkul karimah, berpengetahuan yang cukup sebagai bekal masuk perguruan tinggi.

4. Perenial-Esensialis Kontekstual-Falsifikatif

Pendidikan kompromis masa lalu dengan jalan melakukan kontekstualisasiuji falsifikasi dan mengembangkan wawasan-wawasan pendidikan Islam masa kekinian. Artinya, model ini mengambil jalan tengah dengan menghadirkan pemikiran pendidikan Islam masa lalu. Tetapi disisi lain, konsep pemikiran pendidikan Islam di masa lampau juga dilakukan kontekstualisasi serta uji falsifikasi dan mengembangkan konsep pengembangan pendidikan Islam masa sekarang untuk memenuhi perubahan zaman yang berkaitan dengan ilmu pengetahuan, teknologi dan perubahan sosial lainnya. ${ }^{43}$ Kalangan ini menghargai produk yang dihasilkan oleh ulama terdahulu tanpa menafikan situasi kekinian. Tradisi keilmuan era salaf dan ulama setelahnya tetap menjadi pedoman untuk mengkaji masalah yang muncul dewasa ini. Dengan kata lain, pemikiran pendidikan Islam ini terus dinamis dengan menghargai pemikiran terdahulu.

Dari hasil pengmatan peneliti, perumusan kurikulum pendidikan Islam di pesantren Mambaul Ulum Bata-Bata, kini terbuka tidak seperti yang dituduhkan kaum modernis bahwa pesantren merupakan lembaga Islam yang jumud dan kaku. Kini pesantren Bata-Bata selalu mengkaji perubahan sosial dengan melakukan kajian terhadap kitab klasik. Bahkan bukti yang paling nyata, adanya kitab Fiqh Sosial yang dikarang oleh kiai Sahal Mahfud. Itu sebagai bukti bahwa pendidikan Islam di pesantren Bata-Bata sangat dinamis tetapi tidak menghilangkan karakteristik ulama terdahulu bagaimana proses mengembangan pendidikan Islam. Pesantren tetap melaksanakan dan menjaga tradisi ulama terdahulu dengan mempelajari kitab-kitab klasik. Tetapi disisi lain, pesantren juga melakukan kontekstualisasi pemikiran lama untuk menjawab tantangan kekinian. Terbukti banyak pesantren yang memberikan keterampilan untuk bekal para santrinya menghadapi perubahan zaman. ${ }^{44}$

Hal demikian sesuai dengan hasil wawancara peneliti dengan salah satu ustdzah yakni ustdzah qurrotul Aini, berikut paparannya:

"banyak beranggapan bahwa pesantren bata-bata adalah pesantren yang jumud, kaku dan tidak mengikuti perkembangan zaman. Saya rasa tidak, pesantren batabata tidak menafikkan atas perkembangan IPTEK, bata-bata sangat legowo untuk kemajuan pesantren ini khususnya dibidang Pendidikan. Bata-bata ini dinamis namun tidak menghilangkan karakteristik ulama terdahulu dalam pengembangan

\footnotetext{
43 Muhaimin, Wacana Pengembangan, 130.
}

44 Observasi 4 November 2021 
Pendidikan. Kurikulum yang kami gunakan disini kuikulum K-13, adanya lab, mengirim lomba-lomba nasional seperti matematika, sains dll"45

Hal ini juga sependapat dengan ustdzah faridah, selaku wali kelas MA di pesantren, berikut papaprannya:

"santri bata-bata kini meskipun ada di dalam pesantren, tapi santri ketika keluar dari pesantren tidak ketinggalan zaman, karena di pesantren banyak di pelajari ilmu-ilmu klasik seperti logis, prakom, fikih, genius dll"46

Berdasarkan hasil analisis dokumen dapat dibuktikan dengan adanya RPP, bangunan sekolah, piagam kejuaraan, dan kitab kitab klasik serta para pembimbing kitab-kitab klasik yang berasal dari senior santri di Mambaul Ulum Bata-bata. ${ }^{47}$

\section{Rekontruksi Sosial Berlandaskan Tauhid}

Dalam pengertian luas, pendidikan mampu melahirkan pribadi yang memiliki pengetahuan yang mempuni dan skill yang memadai dengan landasan akhlak yang mulia untuk sepenuhnya mengabdikan diri kepada Allah. Dari sinilah, model rekontruksi sosial berlandaskan tauhid dapat menjadikan terapi untuk masyarakat maju, individualis dan patologis. ${ }^{48}$ Tipologi ini lebih mengedapankan sikap proaktif dan antisipatif dalam pengembangan pendidikan. Rekontruksi sosial merupakan bagian dari tujuan pendidikan Islam sendiri. Maka, pendidikan yang ditanamkan adalah pendidikan akhlak atau perilaku yang sesuai dengan ajaran Islam, memandang orang lain sama dengan posisi dirinya sehingga tidak mudah bersifat sarkastis atau arogan yang tidak diperbolehkan dalam Islam. Sikap toleransi dan menghargai adalah bingkai kehidupan yang harus dijalani terutama bagi mereka yang memiliki pengetahuan memadai.

Model pengembangan pendidikan seperti ini sebenarnya sudah diterapkan pesantren. Sikap kebersamaan selalu ditunjukkan oleh masyarakat pesantren dalam semua hal. Salah satunya ketika santri melaksanakan belajar kelompok. Disana telah tertanam nilai-nilai kebersamaan sehingga untuk menghadapi masyarakat yang individualistik, anak didik tidak akan kaku. Disamping itu, sifat toleransi dalam dunia pesantren sudah menjadi ruh. Dengan kata lain, model pemikiran pendidikan Islam semacam ini selaras dengan dunia pendidikan Islam yang berkembang di pesantren. Hal ini sabagimana paparan dari salah satu ustadz yakni ustadz Idris selaku guru di tingkat MA Bata-bata:

\footnotetext{
${ }^{45}$ Qurratul Aini, Ustadzah Santri Putri (wawancara langsung 7 November 2021)

${ }^{46}$ Faridah, Ustadzah Santri Putri (wawancara langsung 7 November 2021)

47 Dokumen tentang RPP dan paiagam kejuaraan

${ }^{48}$ Muhaimin, Wacana Pengembangan, 135. 


\begin{abstract}
"sikap dan sifat toleransi yang ada di bata-bata ini sangat di jaga, hal ini dapat dilihat dari adanya kegiatan kegiatan kajian kitab klasik yang diletakkan di lapangan dengan berkelompok, selain itu kebersamaan yang dijalani setiap hari baik di luar asrama ataupun di dalamnya, dengan kebersamaan setiap hari santri akan mempunyai bekal yang baik terutama dala berkomunikasi mempunyai jiwa sosila yang tinggi dan saling menolong satu sama lain. Disini sangat jelas bahwa penanaman nilai nilai akhaak dan etika akan Nampak dan akan berguna setelah santri keluar dari pesantren." 49
\end{abstract}

Dari hasil pengamatan peneliti, di pesantren Mambaul Ulum Bata-bata sudah terbiasa dengan sifat toleransinya, kebersamaan para santri dimulai ketika belajar bersama, tidur bersama, sekolah bersama, kajian kitab bersama. Nampak setiap pagi ada kajian kitab klasik berkelompok di halaman sekolah, ngaji al-Qur'an secara sorogan di dalam musholla, dan ada kegiatan bersama di masing-masing asrama. Dalam membangun etika dan kekompakan yang baik, santri dengan sabar berantrian mandi dan makan. Selanjutnya, toleransi santri Nampak ketika kolaborasi santri baru dan santri lama, saling menunjukkan keakraban.

\title{
D. Kontribusi Pondok Pesantren Mambaul Ulum Bata-bata
}

Di tengah kegaduhan dan kegelisahan masyarakat atas perkembangan modernisasi yang terus maju tapi mengalami kekeringan spiritual, lembaga pendidikan pesantren semakin 'dicari' karena mampu membuktikan out put berciri khas yang tak dimiliki sisitem pendidikan umum. Sebab pesantren tidak hanya sebagai lembaga pendidikan tetapi juga sebagai lembaga sosial yang mampu menyelesaikan sejumlah persoalan yang terjadi ditengah-tengah masyarakat.hal demikian sesuai dengan hasil wawancara peneliti dengan salah satu ustad yakni ustad rosi, berikut paparannya:

"Pesantren pada saat ini sangat diperioritaskan oleh bangsa, karena kontribusinya terhadap Pendidikan khususnya. Memang banyak pendidik hebat di luar sana pemikirannya sangat luas namun melihat perkembangan zaman dan tekhnologi saat ini bangsa lebih membutuhkan pendidik yang tidak kekeringan spritual "50

Diperjelas lagi oleh hasil wawancara peneliti dengan salah satu pengurus podok pesantren yakni ustadzah anis, berikut paparannya:

"santri ketika keluar dari pesantren memang banyak dibutuhkan oleh masyarakat khususnya dalam membimbing dan mendidik dibidang agama, karena ketika santri keluar dari pesantren outputnya tidak diragukan lagi. Sangat urgen sekali peran dan kontribusi santri untuk bangsa sehingga ada peringatan tentang hasi santri nasional. Di-bata-bata ini ada 18 program akselerasi yang bisa dikuasai santri, sehingga ketika santri terjun ke lapangan tidak kebingungan. Meskipun ilmu yang santri peroleh hanya dalam lingkup

49 Idris, Ustad santri putra (wawancara 7 November 2021)

${ }^{50}$ Rosi, Ustad santri putra, Wawancara langsung (6 November 2021). 
pesantren akan tetapi nilai jualnya dan kontribusinya sangat luar biasa melebih mereka yang memperoleh ilmu di luar pesantren"51

Peneliti mengamati bahwa di pesantren Mambaul Ulum Bata-bata santri banyak berkontribusi terhadap bangsa. Nampak setiap pagi santri selalu dibekali dengan ilmu agama dari 18 program akselerasi di antaranya, bidang KUTUBIYAH (prakom, logis, arkom, fikish, alfan's, genius, minicom, armin, aimna, kastaqin), bidang BAHASA (LPBA, BBEC, BTC, korea, german), bidan AL-QUR'AN dan SENI (TPQ, jami'iyatul khottot, jai'iyatul qurro') dan masih banyak lagi kajian-kajian kitab lainnya. Dengan banyaknya ilmu-ilmu yang bisa dikembangkan secara kreatif oleh santri maka output santri bata-bata bisa dikontribusikan dengan baik dan mempunyai nilai jual yang tinggi khusunya di masyarakat. ${ }^{52}$

Dengan hasil analisis dokumen yang menunjukkan adanya sertifikat santri yang sudah di I'lan dalam tema TAMARA yang diselenggarakan di acara pekan ngaji setiap bulan Januari, dan analisis dokumen bahwa pesantren sebagai Lembaga sosial yang perannya sangat dibutuhkan di masyarakat hal ini dapat ditunjukkan dengan adanya pengiriman guru tugas ke luar pesantren bahkan sampai luar kota dan negri yang di buktikan dengan adanya surat tugas. ${ }^{53}$

Pesantren selalu berusaha mendekati masyarakat untuk mewujudkan pembangunan sosial masyarakat desa. Warga pesantren telah terlatih melaksanakan pembangunan kesejahteraan masyarakat khususnya, sehingga terjalin hubungan yang harmonis antara santri dan masyarakat, antara kiai dan kepala desa. Pesantren sampai saat ini memiliki pengaruh cukup kuat pada hampir seluruh aspek kehidupan dikalangan masyarakat muslim pedesaan yang taat. ${ }^{54}$ Pengaruh pesantren Mambaul Ulum BataBata, mampu mempengaruhi manca negara, jadi tidak hanya dalam negara di luar negara pun terpengaruh terhadap sistem pendidikan di pesantren tersebut.

Dalam konteks pengembangan pendidikan Islam, pesantren dibagi ke dalam bebarapa kategori: Pertama, pondok pesantren salafiyah adalah pondok pesantren yang menyelenggarakan pembelajaran dengan pendekatan tradisional, menggunakan pembelajaran sorogan, wetonan dan bandongan. Pondok salaf ini sampai sekarang masih banyak yang eksis. Dalam pembelajarannya, pondok ini mengajarkan santrinya dengan dominan ilmu agama yang dilaksanakan secara individual atau kelompok dengan

\footnotetext{
51 Anis, Ustdazh santri putri, Wawancara langsung (6 November 2021).

52 Observasi, 1-2 november 2021

53 Dokumentasi tentang sertifikat santri I'lan TAMARA

${ }^{54}$ Abd. A’la, Pembaruan Pesantren ( Yogyakarta: Pustaka Pesantren, 2006), 1. 
konsentrasi pada kitab-kitab klasik, berbahasa Arab kepada kyai dan ustadz. Penjenjangan tidak disasarkan pada satuan waktu, tetapi berdasarkan tamatnya kitab yang dipelajari. Dengan selesainya satu kitab tertentu, santri dapat naik jenjang dengan mempelajari kitab yang tingkat kesukarannya lebih tinggi. Demikian seterusnya. ${ }^{55}$ Model pembelajaran ini dapat memberikan pemahaman yang tuntas bagi santri. Santri diharapkan mampu bisa membanca kita klasik berbahasan Arab dan menerjemahkannya. Sehingga selain santri mampu memahami isi kitab juga dapat membca literatur ilmu agama dengan benar.

Kedua, pesantren modern ditandai dengan sisitem pendidikan formal mulai dari MI, MTs, MA, bahkan Perguruan Tinggi (PT) atau sekolah dari SD, SMP, SMA atau SMK. Di Pondok modern siswa tidak hanya mendapatkan pengetahuan agama tapi juga pengetahuan umum sehingga pondok lebih banyak berfungsi sebagai asrama yang memberikan lingkungan kondusif untuk pendidikan agama, sementara pengetahuan umum melalui klasikal di madarasah. Di model pesantren ini, pengetahuan bahasa asing -Arab dan Inggris- bahkan mandarin biasanya menjadi salah satu materi yang diwajibkan kepada santri di pesantren Mambaul Ulum Bata-Bata.

Model pesantren yang ketiga adalah pesantren Campuran/Kombinasi antara salaf dan modern. Disini sistem pembelajaran sama-sama berjalan, antara pendidikan tradisional dan modern. Santri juga diajari kitab klasik seperti pada pondok salaf serta pengetahuan umum dengan bentuk klasikal. Biasanya di dalamnya santri diwajibkan pula berbahasa Arab dan Inggris secara aktif dalam pergaulan sehari-hari.

Menyikapi model pesantren campuran ini, pemerintah melalui Kementerian Agama mengkategorikan jenjang pendidikan pesantren dalam tiga jenjang, yaitu tingkat dasar, tingkat menengah pertama dan tingkat menengah lanjutan. ${ }^{56}$ Pada penjelasan berikutnya disertai dengan kurikulum atau materi-materi pelajaran yang diajarkan. Pembelajaran kitab klasik tidak hanya diajarkan dengan sistem sorogan atan bandongan, tetapi juga dimasukkan dalam kurikulum madrasah. Biasanya pengetahuan agama seperti ilmu fiqh menggunakan kitab klasik sesuai dengan kondisi pesantren masing-masing.

Dengan demikian, dinamika pembelajaran di pesantren Mambaul Ulum tidak lagi fokus mendalami keilmuan agama tetapi diperluas kepada ilmu umum bahkan memiliki jurusan atau spesifikasi seperti jurusan IImu Pengetahuan Alam (IPA), IImu Pengetahuan

\footnotetext{
55 Muhammad Rouf, Memahami Tipologi Pesantren dan Madrasah sebagai Lembaga Pendidikan Islam Indonesia (Tadarus, 2016), 75-82.

56 Ibid, 82.
} 
Sosial (IPS) serta melatih anak didik dengan keterampilan dan skil sehingga mengalami perkembangan yang luar biasa, baik yang ada di pesantren maupun di luar pesantren. Terbukti madrasah kini sudah masuk pada sistem pendidikan nasional. Sejak tahun 1975, Madrasah Ibtidaiyah (MI), Mandrasah Tsanawiyah (MTs), dan Madrasah Aliyah (MA) dianggap setara dan mendapat pengakuan dari negara dengan Sekolah setingkat seperti Sekolah Dasar (SD), Sekolah Menengah Pertama (SMP) dan Sekolah Menengah Atas (SMA).

Dari tiga model pendidikan di pesantren itu tidak bisa lepas dari pengaruh tipologi pemikiran pendidikan Islam yang dijalaskan pada bagian sebelumnya. Tipologi pemikiran pendidikan Islam memiliki peranan penting dalam pengembangan pendidikan Islam terutama dalam pesantren sebagai institusi pendidikan Islam tertua di Nusantara.

\section{E. Kesimpulan}

Setelah melakukan penelitian secara mendalam, di pondok pesantren Mambaul Ulum Bata-bata setidaknya ada enam tipologi yang mempengaruhi pengembangan pendidikan Islam, di antaranya: tipologi pesantren salaf, tipologi pesantren modern, tipologi pesantren campuran antara modern dengan salaf. Corak pesantren salaf dengan model pendidikan yang konsisten menjaga tradisi ulama klasik dengan model pembelajaran seperti sorogan dan bandongan. Kemudian tipologi salafi dan mahzabi, serta tipologi bercorak perenial-esensialis kontekstual-falsifikatif dan tipologi rekontruksi sosial berlandaskan tauhid. Pengaruh pemikiran tersebut dipengaruhi oleh bacaan yang dijadikan rujukan. Seperti pengaruh pemikiran Imam Syafi'ie yang begitu kuat. Pesantren ini menjadikan kitab-kitab aliran Syafi'ieyah sebagai pelajaran wajib bagi santri. Pesantren Mambaul Ulum Bata-Bata Pesantren adalah lembaga pendidikan islam asli Indonesia yang ada di Madura yang tetap mempertahankan kultur kepesantrenannya dengan senantiasa merespon perkembangan zaman yang ada. Menerapkan model pendidikan salaf dan khalaf secara terpadu, mampu mempengaruhi masyarakat di sekitarnya dalam mengembangkan pendidikan Islam. Pesantren ini terus berkembang secara dinamis, mereformasi diri, sehingga menjadi lembaga pendidikan Islam masa depan.

\section{F. Referensi}

A’la, Abd. Pembaruan Pesantren. Yogyakarta: Pustaka Pesantren, 2006.

Abasri. Sejarah Pendidikan Pesantren. Jakarta: Kecana, 2007. 
Afrizal. Metode Penelitian Kualitatif Sebuah Upaya mendukung Pengunnaan Penelitian Kualitatif Dalam Berbagai Disiplin Ilmu. Jakarta: Rajawali Pers, 2016.

Ajijola, Alhaji A.D. Re-Structuring of Islamic Education. Delhi: Adam Publishers \& Distributors, 1999.

AR, Zaini Tamin, et. al. “MENAKAR BUDAYA LITERASI DI PESANTREN; Siginifikansi Dan Relevansi Metode Programme for International Student Assessment". FIKROTUNA, Vol. 13, No. $01 \quad$ (2021). https: / / doi.org/10.32806/jf.v13i01.4356.

Asy’ari, KH. Hasyim. Adâb al- ‘Âlim wa al-Muta'alim”. Suwendi, Sejarah dan Pemikiran Pendidikan Islam. Jakarta: RajaGrafindo Persada, 2004.

Az-Zarnuji. Ta'lim Muta'allim. Kediri: Mukjizat, 2015.

Baso, Ahmad. Pesantren Studies 4a. Jakarta: Pustaka Afid, 2013.

Baso, Ahmad. Pesantren Studies a2. .Jakarta: Pustaka Afid, 2013.

Biklen, S.K \& Bogdan, R.C. Qualitative Research for Education: An Introduction to Theory and Methods. Third Edition. Boston: Ally and Bacon, Inc, 1998.

Daulay, Haidar Putera. Pendidikan Islam Dalam Perspektif Filsafat. Jakarta: Kencana Prenada Media Group, 2014.

Dhofier, Zamakhsyari. Tradisi Pesantren : Studi Pandangan Hidup Kyai dan Visinya Mengenai Masa Depan Indonesia. Jakarta: LP3ES, 2011.

Djunaidi, Mahbub. Asal Usul; Catatan-Catatan Pilihan. Yogyakarta: Ircisod, 2018.

Echols, John dan Hassan Shadily. Kamus Inggris Indonesia. An English-Indonesian Dictionary.

Ginanjar, Agustian Ary. Rahasia Sukses Membangun Kecerdasan Emosi dan Spiritual ESQ. Jakarta: Arga Publishing. 2007.

Haningsih, Sri. Peran Strategis Pesantren, Madrasah Dan Sekolah Islam Di Indonesia. EL TARBAWI, 2008.

Madjid, Nurcholish. Bilik-Bilik Pesantren: Sebuah Potret Perjalanan. Jakarta : PT. Dian Rakyat, 2004.

Mahmud, A. \& AR, Z.T. "Transformasi Pesantren (Studi terhadap Dialektika Kurikulum dan Kelembagaan Pondok Pesantren Rifaiyah Pati)", EL-BANAT: Jurnal 
Pemikiran dan Pendidikan Islam Vol. 9 No. 2 (2019). https://doi.org/10.54180/elbanat.2019.9.2.156-176.

Masrur, Achmad. Modernisasi Pendidikan Islam: Telaah Pemikiran Azyumardi Azra Tentang Modernisasi Pendidikan Islam Di Indonesia. unpublished PhD Thesis, Universitas Islam Negeri Maulana Malik Ibrahim, 2014.

Masruroh, Ninik dkk. Modernisasi Pendidikan Islam Ala Azyumardi Azra. Yogyakarta: ArRuzz Media, 2011.

Mohamed, Mohamed Tolba Said, et. al., “INNOVATION IN ISLAMIC EDUCATION”. Hayula: Indonesian Journal of Multidisciplinary Islamic Studies, Vol. 2, No. 2 (July 2018): 117-128.

Muhaimin. Pengembangan Kurikulum Pendidikan Agama Islam di Sekolah, Madrasah dan Perguruan Tinggi. Jakarta: RajaGrafindo Persada, 2007.

Muhaimin. Pengembangan Kurikulum Pendidikan Agama Islam di Sekolah , Madrasah, dan perguruan Tingggi. Jakarta: Rajagrafindo, 2010.

Muhaimin. Wacana Pengembangan Pendidikan Islam. Yogyakarta: Pustaka pelajar. 2003.

Mustafa. Mazhab Filsafat Pendidikan Dan Implikasinya Terhadap Pendidikan Islam. Jurnal Pendidikan Islam Iqra', 2018.

Muttaqin, Ali. Implikasi Aliran Filsafat Pendidikan Dalam Pengembangan Kurikulum Pendidikan Islam. Dinamika,2016.

Niyozov, S., \& Memon, N. "Islamic Education and Islamization: Evolution of Themes, Continuities and New Directions", Journal of Muslim Minority Affairs, Vol. 5 (2011): 30 .

Qomar, Mujamil. Menggagas Pendidikan Islam. Bandung: Remaja Rosdakarya, 2014.

Rouf, Muhammad. Memahami Tipologi Pesantren dan Madrasah sebagai Lembaga Pendidikan Islam Indonesia. Tadarus, 2016.

Rusydiyah, Evi Fatimatur. "Konstruksi sosial pendidikan pesantren: analisis pemikiran Azyumardi Azra", Jurnal Pendidikan Agama Islam (Journal of Islamic Education Studies) Vol. 5, No. 1 (2017). https://doi.org/10.15642/jpai.2017.5.1.21-43. 
Saekhotin, Sayyidah. Dialektika Fundasional Perkembangan Pesantren (Perspektif Pendidikan Islam. Al- Qodiri: Jurnal Pendidikan, Sosial Dan Keagamaan, 2013.

Saridjo, et. al Marwan. Sejarah Pondok Pesantren di Indonesia. Jakarta: Dharma Bhakti, 1983.

Suharto, Toto. Filsafat Pendidikan Islam. Yogyakarta: Ar-Ruzz Media, 2014.

Suhartono, Suparlan. Sejarah Pemikiran Filsafat Modern. Yogyakarta: Ar- Ruzz, 2005.

Ulfatin, N. Metode Penelitian Kualitatif di Bidang Pendidikan: Teori dan Aplikasinya. Malang: Banyumedia Publishing, 2013.

Wahyu, Muqayyidi Andik. Menuju Pemetaan Tipologi Pemikiran Pendidikan Islam : Tipologi Prenial-Esensialis Kontekstual-Falsifikatif Tentang Pendidikan Islam tadzkiriah, 2016. 